\title{
O caráter científico da Teologia a partir da conferência Fenomenologia e Teologia de Martin Heidegger
}

\author{
Luís Gabriel Provinciatto* \\ Renato Kirchner**
}

\section{Resumo}

O presente artigo toma a conferência Fenomenologia e teologia, proferida pelo filósofo alemão Martin Heidegger, em 1927, como principal fonte teórica e, a partir dela, tece algumas considerações a respeito da positividade e da cientificidade da teologia. A primeira tarefa, nesse sentido, trata justamente de visualizar a teologia como possibilidade de compreensão da fé, mostrando o seu viés fático-hermenêutico, de onde a necessidade de, num primeiro momento, ser introduzido à conferência. Daí decorre a necessária compreensão do positum próprio à teologia, e quais são suas configurações específicas para que seja qualificado enquanto objeto de uma ciência. Esse movimento compreensivo incide na cientificidade própria da teologia: as características de tal cientificidade encontram-se justificadas tanto na conferência quanto no contexto que a circunda.

Palavras-chave: Teologia. Fenomenologia. Positividade. Cientificidade. Martin Heidegger.

\section{The Scientific Character of Theology From Martin Heidegger's Phenomenology and Theology Conference}

\footnotetext{
Abstract

This article aims to present the conference Phenomenology and theology spoken by the German philosopher Martin Heidegger in 1927 as the main theoretical source. From

* Universidade Federal de Juiz de Fora (UFJF). Doutorando em Ciência da Religião pela Universidade Federal de Juiz de Fora (UFJF) com bolsa de fomento Capes. Mestre em Ciências da Religião e licenciado em Filosofia, ambos pela PUC-Campinas. Lattes: http:// lattes.cnpq.br/8472704203242937.lgprovinciatto@hotmail.com .

** PUC-Campinas. Doutor em Filosofia pela UFRJ, professor em cursos de graduação e pesquisador do Programa de Mestrado Strico Sensu em Ciências da Religião na Pontifícia Universidade Católica de Campinas (PUC-Campinas). Lattes: http://lattes.cnpq. br/5079313371476684.renatokirchner@puc-campinas.edu.br.
} 
that, he makes some considerations about the positivity and scientificity of theology. The first task, in this sense, deals precisely with the theology preview as a possibility of understanding the faith, showing its hermeneutic-fact trend, and, from that, the need, in a first moment, to be introduced at the conference. From there, it follows the necessary understanding of which is the positum proper to theology and what are its specific configurations so that it is qualified as the object of a science. This understanding movement focuses on the scientificity proper to theology: the characteristics of such scientificity are justified both in the conference and in the context surrounding it. Key-words: Theology. Phenomenology. Positivity. Scientificity. Martin Heidegger.

\section{El Carácter Científico de la Teología a partir de la Conferencia Fenomenología y Teología De Martin Heidegger}

\section{Resumen}

En este artículo se toma la conferencia Fenomenología y teología, impartida por el filósofo alemán Martin Heidegger, en 1927, como la principal fuente teórica y de ella se exponen algunas consideraciones acerca de la positividad y cientificidad de la teología. La primera tarea, en este sentido, es hacer ver la teología como una posibilidad de comprensión de la fe, mostrando su rasgo fáctico-hermenéutico; de ahí la necesidad de que, en un primer momento, se presentó a la conferencia. De ahí la necesaria comprensión de lo que es el positum propio de la teología y cuáles son sus configuraciones específicas para ser calificado como un objeto de una ciencia. Este movimiento comprensivo incide en la propia cientificidad teológica: las características de tal cientificidad se justifican tanto en la conferencia y en el contexto que la rodea.

Palabras clave: Teología. Fenomenología. Positividad. Cientificidad. Martin Heidegger.

\section{Introdução}

A perspectiva inicial deste trabalho é formalizar a teologia enquanto possibilidade de compreensão da fé religiosa, mostrando sua pertinência científica. Nesse sentido, antecipa-se a intenção de mostrar a teologia como a ciência da fé fundamentada a partir do solo da facticidade, o que lhe dá um caráter derivado, mas que resguarda, ao mesmo tempo, a originariedade da experiência religiosa. Vale ressaltar, a princípio, a ideia de uma "ciência originária", capaz de resgatar e resguardar as fontes experienciais e ter como principal característica a atitude compreensivo-interpretativa das vivências. A ciência, então, aparece como sendo um modo, e não o único, de exprimir a facticidade da existência, ocupando-se mais em compreender o modo como se realizam do que com o conteúdo objetivo apresentado. Ter sempre em mente o como (Wie) da realização é, seguramente, o melhor meio para compreender o que aqui será exposto, pois é justamente o como que "estabelece a relação intencional entre a vida e o mundo ao qual se refere" (SANTOS, 2013, p. 114). 
O objetivo aqui proposto, então, é o seguinte: fazer notar esse entendimento da teologia enquanto ciência derivada, apresentando o positum próprio à teologia, bem como, a cientificidade que lhe é inerente. Visando alcançar tal objetivo, a conferência Fenomenologia e teologia (Phänomenologie und Theologie), proferida por Martin Heidegger (1889-1976), em 1927, apresenta-se como um campo plausível para tal discussão, pois aí a teologia é devidamente problematizada em sua positividade e cientificidade. ${ }^{1}$ Deve-se atentar ainda para o seguinte recorte: a teologia aqui indicada se refere unicamente à cristã, conforme apontado pelo próprio filósofo alemão ao longo da conferência.

Isso poderá ser percebido a partir de três momentos exibidos na sequência: o primeiro deles pretende conduzir o leitor ao interior da conferência Fenomenologia e teologia, fazendo perceber o jogo existente entre a filosofia, compreendida por Heidegger como sendo a própria fenomenologia ontológico-hermenêutica, e a teologia: depreende-se disso a relação entre a ciência ontológica - a filosofia - e uma ciência ôntica - a teologia. Após esse movimento introdutório, é possível compreender qual seja o positum próprio à teologia cristã, suas principais características e por que ele pode se apresentar como objeto científico, ou seja, do segundo momento decorre necessariamente o terceiro: a teologia em sua cientificidade; aí a discussão gira em torno de quais são as características fundamentais à ciência ôntica e, sobretudo, por que a teologia pode ser classificada como tal.

\footnotetext{
Deve-se ter em mente a estrutura da conferência, como apresentada no volume 9 da Gesamtansgabe: Prefácio, datado de 27 de agosto de 1970; o texto propriamente dito, que corresponde, na verdade, à segunda parte da conferência; tal texto está sob o título $A$ positividade da teologia e sua relação com a fenomenologia e foi exibido, respectivamente, em Tübingen, em 8 de julho de 1927, e repetido em 14 de fevereiro de 1928, em Marburgo; um Apêndice, datado de 11 de março de 1964, contendo Algumas indicações sobre alguns pontos de vista principais para o diálogo teologico a respeito de "O problema de um pensar e dizer não objetivantes na teologia de hoje”. Destaca-se ainda a importância das datas desses escritos, pois elas mostram épocas distintas, nas quais o modo de Heidegger lidar com a questão a respeito do ser é diferente. Nota-se isso quando, por um lado, na conferência na década de 1920 uma das questões era mostrar a positividade da ciência e, por outro, a preocupação exposta no apêndice ser justamente lidar com uma linguagem teológica não objetivante, bem como, com a possibilidade de diálogo da teologia com outras ciências. O presente trabalho, visando uma maior precisão objetiva, atém-se à discussão e problematização a respeito da positividade e cientificidade da teologia, não abordando nem as ricas indicações do prefácio nem as provocadoras palavras do apêndice.
} 


\section{Fenomenologia e Teologia: uma introdução}

Um dos primeiros tópicos a ser percebido no contexto da conferência é o seguinte: ao propor a teologia enquanto possibilidade de compreensão da fé não se está pautando sua oposição à filosofia. Em outras palavras: não se trata de conceber a filosofia como explicação racional da realidade e a teologia como explicação cega da mesma realidade, visto que a teologia não se pautaria na razão, mas sim em dados de fé. Na verdade, ambas não se propõem nem a explicar a realidade, pois esta já seria uma tarefa imposta a elas. Ambas compreendem a realidade. E mais: compreendem a realidade a partir daquilo que é mais próprio e comum às duas, a realidade efetiva do ser-aí. Isso significa que tanto a filosofia - compreendida na conferência como sendo a própria fenomenologia - quanto a teologia são fático-hermenêuticas, pois estão dispostas na própria realidade do ser-aí: "a hermenêutica concentra-se na vida, enquanto se manifesta como um todo aberto, dinâmico e passível de interpretação em função do dinamismo existencial do próprio homem" (GONÇALVES, 2014, p. 935).

Filosofia e teologia, então, são modos próprios de compreender a realidade: a filosofia de maneira ontológica e a teologia em sua onticidade; o que, por ora, somente se anuncia. Não são modos opostos pautados ora na razão e ora na fé. Afirmar isso seria um equívoco, pois, tomando esse ponto de partida, as duas seriam compreendidas em sentido metafísico, isto é, como algo alheio à realidade. Postular a filosofia como explicação racional e a teologia como explicação fideísta seria lidar com ambas de maneira ôntica, impondo-lhes atributos que não são os seus, além de que nessa "suposta diferença" nada mais haveria do que a identidade entre elas, pois o que prevalece aí é justamente o caráter ôntico dado a ambas. Esse alerta a essa concepção vulgar do trato entre filosofia e teologia está nas primeiras linhas da conferência Fenomenologia e teologia:

A concepção vulgar da relação entre teologia e filosofia gosta de orientar-se nas formulações de oposição entre fé e saber, revelação e razão. - Filosofia é a interpretação de mundo e de vida distanciada da revelação e independente da fé; teologia, ao contrário, é a expressão da concepção de mundo e de vida própria à fé, e, em nosso caso, cristã. Tomadas deste modo, filosofia e teologia expressam, então, a tensão e a luta entre dois posicionamentos pautados em uma visão de mundo [...]. Desde o começo, porém, nós concebemos o problema da relação de modo diferente, e, em verdade, como a pergunta da relação entre duas ciências (HEIDEGGER, 2008, p. 58). 
É de capital importância perceber o posicionamento de Heidegger diante da situação: conceber o problema de maneira diferente, ou seja, não como oposição, mas como relação entre duas ciências. Há nas entrelinhas um aporte interessante: ambas são consideradas, desde o início da conferência, como ciências. Isto revela-se, de fato, como sendo um dos objetivos da conferência: apresentar a cientificidade própria da teologia. ${ }^{2}$ A intenção de Heidegger não é dar um caráter científico a uma especulação teológica, mas mostrar que a própria teologia, em si, é científica. De igual maneira, o filósofo não pretende fazer da filosofia a serva ou a senhora da teologia, mas revelar que a filosofia preocupa-se com o ontológico e não com o ôntico, domínio das ciências derivadas, tal qual a teologia. Daí, já se percebe a relação viável entre elas: "a relação entre filosofia e teologia é, então, uma relação entre uma ciência ontológica e uma ciência ôntica, uma ciência que se refere ao ser [a filosofia] e outra que se refere a seu positum [a teologia]" (GONÇALVES, 2011, p. 36).

A viabilidade desse esforço, isto é, de relacioná-las, torna-se possível a partir do entendimento dado pelo próprio Heidegger àquilo que seja ciência: "a ciência é o desvelamento fundante de uma região do ente, ou do ser, a cada vez fechada em si mesma, em virtude do próprio ter sido desvelado" (HEIDEGGER, 2008, p. 59). A ciência, então, lida com entes já desvelados. Não cabe à ciência o papel de desvelar originariamente um ente: o ente deve sempre já ter sido desvelado para que algo como "ciência" seja possível.

2 Esse tópico é de fundamental importância, ou seja, saber que a conferência pretende apresentar a cientificidade própria da teologia. No entanto, se ambas, fenomenologia e teologia, são concebidas desde o início da conferência como ciência, como se orienta a concepção de fenomenologia como ciência? A resposta a esta questão é dada pelo próprio Heidegger na Introdução à conferência: "a respeito do conceito de fenomenologia, que nos serve de guia aqui, e sua relação com as ciências positivas, nos instrui a introdução de Ser e tempo (1927), \ 7" (HEIDEGGER, 2008, p. 56). Isso faz que o leitor retorne ao parágrafo apontado e descubra que nele há a identificação entre fenomenologia, ontologia e hermenêutica: "Ontologia e fenomenologia não são duas disciplinas distintas da filosofia ao lado de outras. Ambas caracterizam a própria filosofia em seu objeto e em seu modo de tratar. A filosofia é uma ontologia fenomenológica e universal que parte da hermenêutica do ser-aí [sic], a qual, enquanto analítica da existência, amarra o fio de todo questionamento filosófico no lugar de onde ele brota e para onde retorna" (HEIDEGGER, 2012, p. 78, grifos do autor). Essa identificação é fundamental para o desdobramento da conferência, pois permite ao próprio Heidegger debruçar-se com maior afinco à problematização da cientificidade da teologia, além de lhe dar um ponto de partida: a existência fática do ser-aí. Isso significa que a aproximação posterior entre fenomenologia e teologia, ambas compreendidas em suas respectivas cientificidades, tem a existência fática do ser-aí como ponto comum. 
Garante-se, com isso, o caráter derivado da ciência, isto é, ela é uma possibilidade de compreensão do ser-aí que já se direciona por uma compreensão prévia do que seja esse ente, dado o prévio desvelamento do próprio ente. E, conforme aponta Marcos Aurélio Fernandes, "é-nos permitido entender que a elaboração teórica da ciência positiva é um desvelamento de algo já desvelado, um desvelamento em segunda potência, portanto, pois antes de se dar o desvelamento científico, já se deu o desvelamento pré-científico do ente" (FERNANDES, 2015, p. 99).

Além disso, a ciência direciona-se sempre a uma região específica e não à totalidade ôntica, por isso a afirmação de que "existem necessariamente duas possibilidades fundamentais de ciência: ciências do ente, ciências ônticas - e a ciência do ser, a ciência ontológica, a filosofia" (HEIDEGGER, 2008, p. 59). Aí está, então, a simples diferença entre filosofia e teologia. Demarcando: o "simples" é sempre o essencial e o mais difícil de ser compreendido, pois é preciso uma guinada no olhar, uma guinada que transcenda o ente e vá em direção ao ser. Nesse sentido, lê-se a tese proposta por Heidegger: "a teologia é uma ciência positiva e, como tal, absolutamente diferente da filosofia” (HEIDEGGER, 2008, p. 59). A precisão de qual seja o positum, o objeto da teologia é fundamental, pois é a partir dele que a ciência teológica se torna possível. Compreende-se também a importância da transcendência - a possibilidade fundamental do ser-aí em sua onticidade questionar o próprio ser, ou seja, a dinâmica da transcendência aponta, em Heidegger, para a superação do ente, questionando o ser - e da hermenêutica da facticidade: elas tornam possível a compreensão prévia do ente revelado, ou seja, só há ciência porque o ser-aí é capaz de previamente compreender isso que se lhe revela e postular o questionamento pelo ser desse mesmo ente. $\mathrm{Na}$ verdade, isso já antecipa também a cientificidade da própria teologia.

Mediante isso, clarifica-se a relação entre filosofia e teologia: "o tratamento é, pois, fenomenológico. O pensar não é, aqui, a descrição de fatos, mas a construção de essências" (FERNANDES, 2015, p. 98). As articulações entre elas, então, não são conflitivas, mas construtivas. Em outras palavras: a teologia ajuda a clarear a experiência religiosa, compreendendo-a em sua positividade; a filosofia direciona-se como estrutura ontológica originária, na qual o desvelar do ente é possível, isto é, a filosofia serve de corretivo ontológico à própria teologia, não lhe sendo nem serva nem senhora, mas parceira. A própria ideia de "construção de essências" situa-se nesse direcionamento, pois confere tanto à filosofia quanto à teologia aquilo que é 
mais próprio a cada uma delas enquanto ciências: o ontológico à filosofia e o ôntico à teologia.

Depreende-se disso um ponto elementar: a compreensão ontológica é anterior à cientificidade ôntica. Deve-se ter isso sempre em vista e atentar para o seguinte:

[...] Heidegger não defende que a filosofia é primeira no sentido de que é um tipo de conhecimento que antecede os outros saberes das ciências. A diferença entre a filosofia e as demais ciências não é somente de posição, mas de natureza. A anterioridade da ontologia se refere ao fato de que quando os entes são encontrados, eles já foram projetados. Essa anterioridade, sentido de a priori, é historicizada, constituindo-se como "essencialmente fática”. A filosofia é mais originária, haja vista que ela tematiza essa compreensão do ser que torna possível o encontro com os entes. É nesse sentido que se pode dizer que as ciências se enraízam na filosofia (PIEPER, 2015, p. 106).

A diferença ontológica ${ }^{3}$ entre filosofia e teologia é fundamental para compreender o próprio caráter científico da teologia, pois, a partir dessa diferença, não há possibilidade alguma de confundir a dimensão ontológica com a ôntica; o que não significa que não há entre elas qualquer relação, pois o ser é considerado sempre como ser do ente. A teologia, então, não é ciência ontológica, pois se caracteriza como compreensão derivada forjada na própria compreensão prévia do ente revelado para ela enquanto positum científico. Isso não significa dizer que ela, enquanto ciência, não zele pela originariedade da própria experiência. Estabelecer qual o positum da teologia é o próximo passo para compreender que, enquanto ciência derivada, a teologia

3 A respeito dessa noção de diferença ontológica, pode-se afirmar o seguinte: ela está fundada na transcendência do ser-aí, ou seja, a diferença ontológica indica o ser-aí como o ente capaz de compreender o próprio ser do ente. A transcendência, conforme indicado no tópico três do primeiro capítulo deste trabalho, fundamenta todo o comportamento do ser-aí, pois todo comportamento é pautado na compreensão de ser. Nesse sentido, Heidegger, na conferência $A$ essência do fundamento (1929), postula uma diferença essencial entre o conhecimento objetivo, pretendido pelas ciências ônticas em geral, e o ontológico, alvo da filosofia: "os conceitos fundamentais da ciência atual não contêm nem já os 'autênticos' conceitos ontológicos do ser do respectivo ente, nem podem estes conceitos ser simplesmente conquistados por uma ampliação 'adequada' daqueles. Muito ao contrário, os conceitos ontológicos originários devem ser conquistados antes de toda definição científica dos conceitos fundamentais" (HEIDEGGER, 2008, p. 144-145, grifos do autor). Nesse sentido, a diferença ontológica e a dimensão da transcendência do ser-aí são fundamentais para compreender a radical diferença entre fenomenologia e teologia, bem como para situar o positum e a cientificidade da última. 
resguarda a originariedade da experiência religiosa, sendo-lhe, inclusive, um modo de compreensão.

\section{A Teologia em sua positividade}

Compreender qual seja a positividade da teologia se apresenta como tarefa fundamental, dado que, de acordo com a própria elaboração heideggeriana, não há ciência sem objeto de investigação. Tal objeto encontra-se, a cada vez, desvelado originariamente na própria existência do ser-aí; esse objeto não pode ser elaborado posteriormente, mas deve ser previamente compreendido em seu manifestar-se. A própria ciência deve possuir um caráter fático, não sendo alheia à existência do ser-aí. Todos esses pontos são notados quando Heidegger estabelece critérios pertencentes à positividade científica.

O primeiro desses critérios: “1) Que, em geral, um ente de algum modo já desvelado possa ser encontrado de antemão em um certo âmbito de abrangência como possível tema de uma objetivação e questionamentos teoréticos" (HEIDEGGER, 2008, p. 60). A esse critério segue aquilo que aqui já foi mencionado: o positum da teologia deve ser previamente estabelecido e direcionado por uma compreensão prévia do ser-aí. O ente próprio da teologia pertence à dimensão pré-teórica e a-reflexiva da existência, podendo ser objetivado tornando-se disponível para uma teorização. $\mathrm{O}$ desvelar desse ente também é peculiar, pois cada ente se apresenta, ou melhor, se dá ao ser-aí numa dinâmica diferente, conforme anota Gonçalves: "cada região é contida de objetos, em função de seu caráter objetivo e do modo de ser dos objetos, e imbuida de um modo especifico de desvelamento, demonstração, fundamentação e cunhagem dos conceitos que dão forma ao conbecimento que dai emerge" (GONÇALVES, 2011, p. 35, grifos do autor). Decorrem disso, então, dois pontos fundamentais: 1) o positum sempre revela um conjunto de possibilidades a serem abordadas; e em tal revelar há também um ocultar, compreendido pelo viés fenomenológico-fático-hermenêutico. 2) É fundamental que, a partir desse campo de possibilidades, delimite-se o ambiente teológico para que ele lide e conceitue, de fato, aquilo que se lhe revela de maneira científica; e, tal como aponta Pieper: "é preciso determinar o que constitui esse positum da teologia, ou seja, cabe identificar o conjunto dos entes que ela abrange" (PIEPER, 2015, p. 109).

O segundo critério próprio à positividade científica indica o seguinte:

2) Que esse positum prejacente possa ser encontrado de antemão em um determinado modo pré-científico de acesso e lida com o ente, e, nesse modo 
de lida, já se mostre o caráter especificamente coisal desta região e o modo de ser do respectivo ente, portanto, antes de toda e qualquer apreensão teórica, mesmo que tenha sido desvelado de modo não-expresso e não-ciente (HEIDEGGER, 2008, p. 60-61).

Isso aponta que o pré-científico possui um modo de compreensão próprio. E mais: esse modo orienta a própria determinação científica, pois o ser-aí sempre opera de maneira fático-hermenêutica a cada vez que compreende a própria existência em sua historicidade. E mais: isso nem sempre precisa estar expresso nem o ser-aí estar ciente de tal possibilidade fundamental. Qual conclusão já se pode antever a partir disso? Eis uma resposta viável: o ser-aí não precisa elaborar teoria para compreender-se como existente; a teoria é uma possibilidade. Com isso, o postulado do teorético é rechaçado por Heidegger. No que tange à teologia, isso significa que não há algo como "teologia pura", pois a própria compreensão do que seja teologia é historicizada e enraizada na existência fática do ser-aí. O ente positivado da teologia é, a cada vez, sempre novo, pois a pertença do ser-aí é sempre histórica. Isso significa que o positum da teologia é compreendido sempre como manifestação significativa ao ser-aí. O comentário a seguir traz justamente esse aspecto, além de apontar para o terceiro critério:

Isso [o caráter pré-científico da compreensão] possibilita e justifica a variação da positividade conforme o caráter concreto do ente, em consonância com o seu modo de ser, com o modo de realização do desvelamento pré-científico do ente correspondente e com o modo de pertença deste desvelamento ao que ali está previamente presente (GONÇALVES, 2014, p. 940).

Antes mesmo da apresentação do terceiro critério sobre a positividade da teologia já é possível perceber que o cristianismo não pode ser alvo da investigação teológica. Deve haver algo elementar ao próprio cristianismo, pois, enquanto evento histórico-cultural, a teologia lhe é constitutiva. Caso o cristianismo fosse o objeto da teologia, ela analisaria a si mesma, pois ela é parte integrante da história daquele. Não haveria a possibilidade de variação da positividade, conforme aponta Gonçalves, o que faria da teologia puramente metafísica.

O terceiro critério aponta para a compreensão pré-científica, mas quer-se destacar de antemão que esse critério resguarda com maior afinco a dimensão originária da vivência e o caráter fenomenal do positum teológico: 
3) Faz parte da positividade o fato de também este posicionamento pré-científico frente ao ente prejacente [...] já ser iluminado e conduzido por uma compreensão do ser, mesmo que ainda desprovida de conceitos. Então, a positividade pode variar de acordo com o caráter coisal do ente, em sintonia com o seu modo de ser, com a maneira como se deu o desvelamento pré-científico do referido ente e com o modo de pertença desse desvelamento ao que está ali pré-jazendo (HEIDEGGER, 2008, p. 61).

Quer-se destacar o seguinte desse terceiro critério: há três possibilidades para que a positividade da ciência sofra variação. 1) O caráter ôntico do próprio ente e sua relação com o seu modo de ser; 2) o como acontece o desvelamento pré-científico do ente; 3) a relação do ente manifesto com o ser-aí ali presente. Isso é muito próximo da caracterização apresentada por Heidegger do que seja fenômeno, pois a experiência, fundamentalmente, “pode-se tornar questionável: 1) pelo 'que' originário, que é experimentado nele (conteúdo); 2) pelo 'como' originário, em que é experimentado (referência); 3) pelo 'como' originário, no qual o sentido referencial é realizado (realização)" (HEIDEGGER, 2010, p. 58). O que isso, no entanto, significa? Significa que o positum da teologia é um fenômeno que, enquanto tal, é vivenciado historicamente de maneira originária a cada vez e não pode ser determinado previamente de maneira teórica nem em seu conteúdo, nem no sentido de referência (Bęug) nem na realização (Vollzug).

Nesse sentido, a possibilidade de apreensão do fenômeno crístico (Christlich), fundamento do próprio cristianismo, é via indicação formal, pois somente se pode indicar sem determinar previamente a experiência. Denomina-se, então, de fenômeno crístico a própria fé enquanto crida; e isso indica que "o fenômeno religioso não é teórico, ou seja, alguma coisa que se pode reduzir a 'fórmulas' prontas ou fixar em 'palavras' ou 'dogmas"' (SANTOS, 2016 , p. 293). No entanto, esse viver religioso pode ser expressado, ou melhor, compreendido por indicações fenomenológicas que não têm somente a intenção de descrever um fenômeno, mas de possibilitar um verdadeiro acesso a ele. De fato, “tais 'conceitos' [fenomenológicos] permitem atingir a vivência em sua motivação originária” (SANTOS, 2016, p. 293). Isso faz que a própria teologia possua o caráter histórico de realização do evento cristão, pois "a teologia se movimenta a partir de dentro do cristianismo, engendrando e sendo engendrada por seu desenvolvimento historial" (PIEPER, 2015, p. 109). Eis, então, o positum teológico: a fé crística, is to é, a cristicidade (Christlichkeit). 
A cristicidade é o que previamente se dá ao ser-aí e, portanto, ela "decide sobre as possíveis formas de teologia enquanto ciência positiva" (HEIDEGGER, 2008, p. 63). Isso também possibilita perceber que a história do cristianismo não é o objeto de investigação da teologia, mas que esta possibilita ao cristianismo assumir-se como fenômeno histórico, pois, na verdade, "chamamos de crístico à fé” (HEIDEGGER, 2008, p. 63). A cristicidade, então, enquanto positum da teologia, aponta para o caráter experiencial-histórico da fé cristã, de onde a possibilidade de afirmar: "o termo Christlichkeit intervém, justamente, no coração de um desdobramento que aponta a oposição entre o primeiro impulso, perfeitamente autêntico, da proclamação evangélica, e um lento processo de desvivificação da fé" (CAPELLE-DUMONT, 2012, p. 33; tradução do autor). ${ }^{4}$

Mediante isso, não se aponta que a teologia desvivifica a fé, positivando-a. O entendimento aqui assumido é justamente pela possibilidade de a teologia cristã resguardar a originariedade dessa experiência crística. Em outra anotação, Capelle-Dumont mostra justamente esse caráter autêntico da fé: "a fé não é resultado de uma analítica existencial, mas daquilo que se revela a partir do que é crido, no fundo de possibilidade do ser-aî" (CAPELLEDUMONT, 2012, p. 33; tradução do autor). ${ }^{5}$ Essa possibilidade de resguardar a originariedade do cristianismo se dá a partir da importância da escritura e da tradição, pois o que estas fazem é justamente guardar a fé a partir de seu caráter histórico. O sentido de realização, com a hermenêutica-fenomenológica, mostra o texto em sua vitalidade primordial, de onde a compreensão de que o fenômeno revelado pela fé só pode ser crido na fé e clarificado para a própria fé. Disso parte a relação ímpar entre o cristão e a cruz:

A relação da fé com a cruz, determinada por Cristo, é uma relação cristã. A crucificação, porém, assim como tudo o que está ligado a ela, aponta para um evento histórico, e, em verdade, esse evento, como tal, é testemunhado na Escritura em sua historicidade específica apenas para a fé. Só se "sabe" deste fato na fé (HEIDEGGER, 2008, p. 63, grifos do autor).

O que primeiramente se revela nessa fé crística é o Cristo - o "Deus crucificado". Além disso, a possibilidade de crença nessa manifestação só é

\footnotetext{
4 "El concepto de Christlichkeit interviene entonces en el corazón de una estrategia que apunta a oponer el impulso primero, perfectamente auténtico, de la proclamación evangélica, y un lento proceso de desnaturalización de la fe."

5 "La fe no resulta de una analítica existencial, sino de aquello que se revela a partir de lo que es creído, en el fondo de posibilidad del Dasein."
} 
possível na e pela fé; isso faz que também se afirme: a teologia visa iluminar a compreensão da própria fé, logo, a teologia é direcionada para a fé. A compreensão do caráter testemunhal dos textos evangélicos só é possível mediante a fé e esta, por sua vez, "é um modo de existência do ser-aí humano” (HEIDEGGER, 2008, p. 63). A teologia, então, postula a fé como objeto de investigação e não se caracteriza uma fuga da realidade histórica e existencial do ser-aí fático, dado que ela mesma, em sua positividade, é fático-hermenêutica. O que a fé revela está direcionado ao ser-aí, fazendo que este esteja existencialmente próximo do Cristo - o Deus crucificado.

Os grifos destacados não são sem intenção: "só se 'sabe' deste fato na $f e$ ". Esse "saber" não é um saber teórico, ou seja, não se toma a fé como um possível objeto, dotado de a-historicidade, e se o transmite a um sujeito. Esse saber é a-reflexivo, anterior a qualquer teoria e explicação, pois se situa justamente na dimensão da compreensibilidade. E mais: na dimensão da compreensão da própria existência agora direcionada pela fé. Há de se concordar com Capelle-Dumont quando ele afirma:

A revelação cristã como tal nunca pode ser comunicada pela simples transmissão de conhecimentos que lidam com um conjunto de acontecimentos passados ou em realização: ela só pode ser "sabida" e comunicada desde o lugar que lhe é próprio, que é a fé (CAPELLE-DUMONT, 2012, p. 35; tradução do autor). ${ }^{6}$

Nota-se, então, uma proximidade muito peculiar entre a dinâmica da transcendência e esse "saber" somente possível na fé, pois ao "saber" deste ato na fé, o ser-aí transcende a própria dimensão ôntica, a primeira a se revelar, e a questiona em seu ser. O "fazer" teologia, nesse sentido, começa a se esboçar como um local viável para resguardar a própria originariedade da experiência religiosa e, por conseguinte, a própria compreensão fáticohermenêutica da existência.

Percebe-se, daí, a importância do texto em seu caráter comunicativo e não somente informativo. A revelação deve ser comunicada, em sentido fenomenológico, pois “a tendência da compreensão fenomenológica é fazer a experiência da objetualidade em sua originariedade [Ursprünglichkeit]" (HEIDEGGER, 2010, p. 69). Esse caráter comunicativo da revelação é apresentado por Heidegger na conferência de 1927 nos seguintes termos: "La revelación cristiana como tal nunca puede ser comunicada por simple transmisión de
conocimientos que traten acerca de un conjunto de acontecimientos pasados o en curso:
sólo puede ser 'sabida' y comunicada desde el interior de su lugar original, que es la fe." 
De acordo com seu caráter específico “de sacrifício”, o que assim se revela possui o seu direcionamento comunicativo determinado na direção do homem individual historicamente existente, a cada vez de maneira fática, seja contemporâneo ou não, ou à reunião desses indivíduos enquanto comunidade. Enquanto revelação, essa comunicação não é uma transmissão de conhecimento sobre acontecimentos reais, passados ou ainda por vir. Ao contrário, ela transforma os individuos em "participante" no evento que é a revelação $=0$ que nela é o próprio revelado (HEIDEGGER, 2008, p. 63, grifos do autor).

De modo muito claro, pode-se perceber uma identificação entre quem vivencia e aquilo que é vivenciado. Essa perspectiva faz que o agente da fé seja transformado e passe a compreender a própria existência a partir da fé e na fé. Além do mais, nota-se a importância da escritura enquanto palavra proclamada: ela não é pura transmissão de conhecimento metafísico e especulativo, mas diz respeito à própria existência do ser-aí. A teologia, enquanto possibilidade de compreender formalmente a fé, não pode ser nem estar alheia a essa realidade existencial do ser-aí, isso porque o cristão não se posiciona diante da fé parcialmente, mas em sua totalidade. Há aí um tomar-parte com significado de fazer-parte: esse é o sentido do termo "participante" já mencionado. Teil-nebmen (tomar-parte) é tão-somente Teil-haben (fazer-parte) e tal fazer-parte indica incisivamente um campo prático, uma ação por parte do crente que, crendo, é partícipe da fé no Cristo crucificado. Essa ideia de duplicidade com o termo "participante" é também apresentada a seguir:

Heidegger indica, desta maneira, a dupla atitude na qual se inscreve a contemporaneidade entre o crente e a Revelação: atitude humana de disposição perante Deus, e atitude divina, antecedente ao primeiro, que revela o existente humano a si mesmo (CAPELLE-DUMONT, 2012, p. 36; tradução do autor). ${ }^{7}$

Desse modo, anuncia-se: a fé se dá pré-teoricamente e tem necessidade de uma prévia compreensão para que seja positivada. A teologia está a serviço da fé somente enquanto possibilidade derivada e forjada na atitude compreensiva do próprio ser-aí: “a fé é, então, aquilo que entra na própria teologia, como tematização que abarca o todo do ente desvelado - o evento revelado - que deve ser zelado pela teologia em seu desenvolvimento como

"Heidegger indica de este modo el doble gesto en el cual se inscribe la contemporaneidad entre el creyente y la Revelación: gesto humano de disposición hacia Dios, y gesto divino, antecedente al primero, que revela el existente humano a sí mismo." 
ciência ôntica" (GONÇALVES, 2014, p. 945). Apesar disso, a fé é sempre fé crida por um ser-aí historicamente existente, de modo que, ao positivar a fé, a teologia traz em seu bojo a própria existência do ser-aí, compreendendo-a, agora, pelos olhos da fé. Por isso, o sentido existencial da fé deve ser o de renascimento: todo o ser do ser-aí é compreendido na e pela fé.

Há também o claro desdobramento de que a fé não somente dá o positum para a ciência teológica, mas que ela mesma é esse positum. A positividade da teologia, portanto, não é somente aquilo que decorre da fé, mas a própria fé e, consequentemente, o ser-aí crente, pois não há fé apartada da existência fática. Isso faz que se afirme, novamente: o positum da teologia é sempre novo. Dá-se também um complemento decisivo: o positum, na verdade, é sempre o mesmo, a cristicidade, o caráter "sempre novo" é a revelação da fé ao ser-aí. Essa revelação é sempre atualizada, pois "quando crê no evento do Deus crucificado, o cristão vivencia uma nova maneira de ser, o renascimento; ele mesmo é, hoje, evento da Revelação" (CAPELLE-DUMONT, 2012, p. 36-37; tradução do autor). ${ }^{8}$

A decorrência da positividade da ciência teológica também já indica qual o caminho a ser percorrido, isto é, o positum antecipa a própria cientificidade da teologia ao lhe indicar a necessidade de não determinar antecipadamente o sentido de referência (Bęug), nem o conteúdo a ser experienciado e, sobretudo, nem o sentido de realização (Volląug) de tal fenômeno. "A teologia, portanto, se funda na fé e está a serviço da fé, à medida que a fé abre uma compreensão pré-científica, por um lado, e não resiste a uma compreensão científica, ou seja, a uma articulação conceptual, por outro lado" (FERNANDES, 2015, p. 103). Mostrar a cientificidade da teologia é, naturalmente, a continuidade do caminho.

\footnotetext{
8 "Cuando cree en el acontecimiento del Dios crucificado, el cristiano experimenta una nueva modalidad de ser, que es el renacimiento; él mismo es acontecimiento de la Revelación para hoy."
} 


\section{A Teologia em sua cientificidade ${ }^{9}$}

O primeiro momento decisivo na conquista de uma cientificidade acontece quando se dá a percepção de que a fé crística é capaz de dar um positum e um método próprio de investigação. Em outras palavras: a teologia configura-se, de fato, como ciência ôntica autônoma e, dessa maneira, a compreensão de sua cientificidade decorre da afirmação subsequente de que ela é ciência da fé e para a fé. Conforme anota Paulo Sérgio Gonçalves: "isso significa afirmar que a teologia é ciência daquilo que se desvela na fé e é uma ciência da conduta do crente, uma vez que não pode e nem se deve prescindir da credulidade" (GONÇALVES, 2011, p. 37-38).

Além disso, interessante perceber que mesmo a positividade incidindo diretamente na cientificidade teológica há um momento de passagem entre esses dois elementos constituintes da própria teologia. Trata-se da passagem entre uma existência compreendida de maneira pré-cristã e a própria compreensão cristã da existência, essa baseada na ideia de renascimento, há pouco trabalhada. Um alerta: não se trata de duas realidades ou duas existências, uma terrena e outra celestial, por exemplo; o cerne da discussão é o modo como o ser-aí compreende a própria existência, a princípio. Essa prévia compreensão, na verdade, direciona a possibilidade de compreender a existência na própria experiência religiosa, na própria experiência crística.

Por mais que a conferência Fenomenologia e teologia (1927) se ocupe em apresentar a teologia em sua positividade e cientificidade não se pode tomar tal discussão como pacífica ou finalizada no próprio pensamento de Heidegger. Isso significa o seguinte: por um lado, Heidegger mostra a teologia como ciência ôntica, a qual tem por objeto a cristicidade; por outro lado, o próprio Heidegger admite, numa carta de 8 de agosto de 1928 - note-se a proximidade com a conferência - endereçada a Elisabeth Blochmann, que não está seguro de tal cientificidade. De fato, lê-se na carta - sob a tradução de Frederico Pieper: "com efeito eu estou pessoalmente convencido de que a teologia não seja uma ciência - mas hoje ainda não sou capaz de mostrá-lo efetivamente, ou seja, em um modo que torne inteligível positivamente a grande função da teologia na história do espírito. A simples negação é fácil, mas dizer o que é a ciência mesma, o que é a teologia, se não é nem filosofia e nem ciência - todos esses são problemas para os quais não queria me ver arrastado para dentro de uma discussão momentânea" (HEIDEGGER; BLOCHMANN apud PIEPER, 2015, p. 103). Isso mostra um panorama interessante não somente em relação à teologia, mas em relação à cientificidade da própria ciência: esse é um período no qual Heidegger está a se questionar sobre a pertinência das investigações científicas e, sobretudo, pelo modo de determinação de seus objetos e métodos, bem como com a efetivação do conhecimento científico. Essa é somente uma possibilidade para se compreender o conteúdo da carta enviada a E. Blochmann. 
A prévia compreensão da existência faz que o ser-aí compreenda, também de maneira prévia, a própria fé. A cientificidade da teologia, então, começa a aparecer como decorrência da própria possibilidade do ser-aí desenvolver algo assim como ciência.

A existência na fé assume uma condição peculiar:

Na fé, quem sabe, possamos dizer que a existência pré-cristã é superada de modo ôntico-existenciário. Mas essa superação existenciária pré-cristã, que pertence à fé como renascimento, significa precisamente que, na existência crente, o ser-aí pré-cristão que foi superado está co-implicado de maneira ontológico-existencial. Superar não significa rejeitar, mas tomar em uma nova disposição (HEIDEGGER, 2008, p. 73-74, grifos do autor).

Isso faz que se afirme: o caráter fenomenológico-fático-hermenêutico da existência do ser-aí faz que a teologia tenha como parceira a própria filosofia, pois esta dispõe o caráter fundamental dos conceitos para que aquela se desenvolva plenamente em sua regionalidade específica. Nota-se aqui a importância da diferença ontológica para a independência das duas ciências: a teologia é ciência autônoma, pois está vinculada a um ente, ao passo que a fenomenologia - filosofia - também mantém sua cientificidade, pois se direciona à questão do ser. Há, com isso, uma eficiente relação entre a cientificidade teológica e a cientificidade filosófica, pois decorre disso a fundamentação ontológica originária do ser do ente que se revela pela fé. Afirma-se, mais uma vez, sob essa perspectiva: o objeto da teologia contínua sendo sempre novo.

Não se pode deixar de notar também que o ser-aí continua envolvido de maneira central nessa passagem e nesse modo de constituição de uma cientificidade própria à teologia. A teologia, porém, ganha cientificidade quanto mais questionar e perscrutar o objeto que lhe é próprio, isto é, a fé crística. Isso faz que a fé seja clareada pela teologia e esta, por sua vez, receba auxílio ontológico da filosofia para poder elaborar de maneira clara seus conceitos. Além disso, a teologia "é ainda uma ciência que brota da fé à medida que é motivada pela própria fé" (GONÇALVES, 2011, p. 38), ou seja, ela não necessita recorrer a outras disciplinas científicas para edificar sua própria estrutura. Isso se torna mais nítido quando se percebe o seguinte: "a cientificidade própria da teologia, por fim, não é esclarecida a partir do solo sistemático das disciplinas científicas, mas no terreno mesmo do ato de 
objetivação da fé" (CAPELLE-DUMONT, 2012, p. 37; tradução do autor). ${ }^{10}$ Isso tem consequências múltiplas, algumas apontadas a seguir.

Pode-se afirmar, antecipadamente: não há uma régua para medir a cientificidade teológica, mas que essa vai aparecendo e clareando a fé à medida que a própria fé se torna objetivamente seu alvo de investigação. Somente preocupando-se com a fé é que a teologia pode ser considerada ciência. Nesse sentido, um dos desdobramentos é mostrar o que a teologia não é:

Segundo o conceito etimológico, teo-logia significa: ciência de Deus. Todavia, de modo algum Deus é o objeto de sua investigação do mesmo modo como os animais são tema da zoologia, por exemplo. Teologia não é conhecimento especulativo de Deus. Tampouco vamos encontrar seu conceito, se ampliarmos seu tema dizendo: o objeto da teologia é a relação de Deus por si mesmo com o homem por si mesmo e vice-versa; neste caso, a teologia seria filosofia da religião ou história da religião, ou simplesmente ciência da religião. Muito menos é ela ciência do homem e seus estados de ser e vivências religiosas no sentido de uma psicologia da religião: uma ciência das vivências, por cuja análise, por fim, devemos acabar descobrindo Deus no homem (HEIDEGGER, 2008, p. 70 , grifos do autor).

De maneira muito consciente afirma-se: a teologia não tem a religião como objeto de investigação. Além disso, a cientificidade própria da teologia não pode partir de outra região ôntica para alcançar sua conceptualização. A cientificidade da teologia está fundada na própria fé e as problemáticas e conceitos que surgirem devem partir única e exclusivamente do ente que para ela se revela. A teologia é ciência daquilo que é crido na fé e tal crença não é, a princípio, um conjunto de valores proposicionais metafísicos, ou seja, o ato compreensivo da fé é anterior a toda e qualquer teoria.

A ideia de restringir a cientificidade da teologia, mostrando o que ela não é, está de acordo, sobretudo, com o segundo tópico do artigo que apontava a positividade da teologia: o ente desvelado deve ser apresentado em determinado âmbito de abrangência. "Teologia é a ciência da fé" (HEIDEGGER, 2008, p. 65), então, não é uma afirmação flutuante, mas consequência necessária dessa delimitação. Daí se compreende também a tarefa científica da teologia: ela não visa criar um sistema com proposições metafísicas, mas

\footnotetext{
10 "La cientificidad propia de la teología, por lo tanto, no es esclarecida sobre la base del sistema general de las disciplinas científicas, sino en el terreno mismo del acto de objetivación de la fe."
} 
compreender a própria fé a partir daquilo que a fé lhe apresenta. A viabilidade de tal tarefa está assentada na justa compreensão do termo "ciência da fé", conforme anotado por Fernandes:

Aqui o genitivo [ciência da fé] não é somente objetivo, mas também subjetivo. Ou seja: a fé, tanto como o crido como o crer, não é somente o objeto da teologia, mas é o sujeito mesmo da teologia, sujeito no sentido de fundamento que motiva e justifica a teologia enquanto tal (FERNANDES, 2015, p. 103-104).

Afirma-se, então: a cientificidade da teologia resguarda a própria originariedade da experiência de fé realizada pelo ser-aí, isso porque a cientificidade decorrente está assentada na própria pré-cientificidade da existência crente. Justifica-se tal posicionamento apontando o seguinte: o caráter prévio do positum, identificado à própria existência do ser-aí, contextualiza de maneira fático-hermenêutica a ciência teológica. E tal como aponta Heidegger: "a teologia é ciência da fé não apenas enquanto toma como objeto a fé e aquilo em que se crê, mas porque ela própria brota da fé. Ela é a ciência que a fé motiva e justifica a partir de si" (HEIDEGGER, 2008, p. 66, grifos do autor).

No entanto, isso leva a um questionamento: a cientificidade da teologia é orientada e motivada pelo seu próprio positum, isto é, pela fé; uma das tarefas da teologia é justamente clarear essa existência na fé; de onde, então, parte a motivação do crente em questionar a fé para clareá-la? Já não bastaria simplesmente crer? Na verdade, a pergunta aqui dirigida é: por que há algo como teologia? E mais profundamente: por que há algo como ciência, dado que a teologia é um modo de compreensão científica?

Essas perguntas podem ser colocadas à conferência Fenomenologia e teologia, mas não podem ser respondidas pela mesma. Um ponto, porém, deve ser levado em consideração: o período no qual acontece a conferência, isto é, em 1927 em Tübingen, sendo repetida em 1928 em Marburgo. Esse é o contexto no qual se dá a publicação de Ser e tempo (Sein und Zeit) (1927). Situar a questão pela cientificidade da teologia é levar em consideração o horizonte apresentado pela analítica existencial de Ser e tempo e perceber: "a obra Sein und Zeit é a espiritualidade do texto Phänomenologie und Theologie" (GONÇALVES, 2014, p. 936). Além disso, também desse período é o curso História da filosofia, de Tomás de Aquino a Kant (Geschichte der Philosophie von Thomas von Aquin bis Kant) (1926-1927), no qual a grande preocupação de Heidegger é situar a questão do ser como a discussão própria e unicamente 
filosófica e, dessa maneira, distinguir a filosofia de qualquer ciência. Pode-se antever nesse curso a problemática entre ciência e filosofia, entre ente e ser. Em suma, anota Helmuth Vetter, o editor da obra:

Embora os autores mencionados [Tomás de Aquino, Descartes, Leibniz e Kant] - inclusive Christian Wolff e Christian August Crusius - tenham em mira uma nova fundamentação da filosofia, o ser, ele mesmo, jamais se torna um problema, mesmo na Antiguidade. É com essa indicação que [Heidegger] termina o curso, que com isso lança uma indicação prévia para a questão central de Ser e tempo (HEIDEGGER, 2009, p. 263).

Vai-se percebendo uma unidade entre a procura pela cientificidade da teologia, elemento singular à conferência de 1927, e o próprio percurso filosófico de Heidegger até o presente momento. De onde a afirmação: a preocupação de Heidegger continua sendo a mesma, ou seja, conduzir a um confronto com o ser, questionando-o. E mais: fazer que o ser-aí compreenda e se veja confrontado com o ser que ele mesmo é e que se dá a todo momento. Isso denota uma unidade conceitual muito típica do pensamento de Heidegger e que, mesmo assim, é difícil de ser percebida. Dessa maneira, ao conduzir uma pergunta sobre "por que há algo assim como teologia?" não se tem como objetivo facilitar a própria compreensão da existência. Na verdade, "a transparência da compreensão da fé [...] ao invés de aliviar o existir crente em seu caráter de decisão, o agrava, isto é, traz à fala a sua seriedade" (FERNANDES, 2015, p. 104) porque conduz o ser-aí a confrontar-se com o próprio ser da fé, logo com o ser que ele mesmo é, pois no ato de crer, na experiência crística, não há distinção entre o crente e o crido.

A resposta, então, às perguntas já mencionadas começa a ganhar forma quando se expande o olhar e se permite encontrar com o $\int 2$ da obra Ser $e$ tempo, no qual o caráter questionador do ser-aí é destacado, bem como, o modo de colocação da questão. Questionar a cientificidade da teologia é ultrapassar a dimensão ôntica e ir à procura do ser, do elemento crístico, dado previamente, pois "todo questionar é um buscar. Toda busca retira do que se busca a sua direção prévia. Questionar é buscar cientemente o ente naquilo que ele é e como ele ê" (HEIDEGGER, 2012, p. 40, grifos do autor). E, com isso, pode-se notar o seguinte: a compreensão prévia do ente não necessita ser expressa nem que o ser-aí esteja ciente dela (HEIDEGGER, 2008, p. 60-61); algo bem diferente acontece quando se questiona o ser do ente, ou seja, quando o ser-aí questiona a fé é porque já há uma com-ciência de tal ato: uma ciência conjunta que 
conjuga a compreensão prévia do próprio ser do ser-aí com a compreensão do crístico em sua cristicidade. Por isso, a transparência da compreensão da fé agrava o existir, pois o coloca em questão. E mais: coloca o próprio ser dessa existência em situação de questionamento.

Nesse sentido, a cientificidade da teologia não pode abdicar de seu solo fático-hermenêutico, pois o que ela almeja clarificar é a própria existência crística do crente, isto é, compreender a fé crendo. Esse "agravamento" científico é notado na seguinte passagem, no mesmo $\int 2$ de Ser e tempo:

Como atitude de um ente que questiona, o questionar possui em si mesmo um modo próprio de ser. Pode-se empreender um questionamento como "um simples questionário" ou como o desenvolvimento explícito de uma questão. A característica dessa última é tornar de antemão transparente o questionar quanto a todos os momentos constitutivos da questão (HEIDEGGER, 2012, p. 40, grifos do autor).

Desse modo, algo como teologia e, indo além, algo como ciência é possível mediante o caráter questionador próprio ao ser-aí. A dimensão desse questionamento, no entanto, está dirigida ao próprio elemento fundamental da questão: a questão do ser. Isso faz que o ente se torne transparente em seu ser. No caso da teologia: que a fé se transpareça em sua cristicidade. Esses elementos fazem que seja sempre colocada, a cada vez, o questionamento sobre o ser.

Isso, porém, não gera um círculo vicioso, pois sempre se repete a questão? De acordo com Heidegger, e aqui se partilha dessa ideia, "na questão sobre o sentido do ser não há ‘círculo vicioso' e sim uma curiosa 'retrospecção ou prospecção’ do questionado (o ser) sobre o próprio questionar, enquanto modo de ser de um ente determinado" (HEIDEGGER, 2012, p. 43-44). E isso significa: o ser-aí sempre se vê posicionado junto ao ente quando caminha (Fahrt) em direção ao ser. Na verdade, a ideia de círculo é bem-vinda, não como círculo vicioso, mas como "círculo hermenêutico": ${ }^{11}$ a identificação do

11 Conforme já indicado por este trabalho, a noção de "círculo hermenêutico" encontra-se presente na obra Ontologia (bermenêutica da facticidade) e entre os $\$ \int 32$ e 38 de Ser e tempo. Mesmo assim, quer-se destacar o seguinte: o círculo hermenêutico abrange a compreensão como uma abertura a possibilidades, o que, na verdade, é muito interessante para a cientificidade teológica, pois garante a ela a abertura a diferentes interpretações ancoradas na compreensão de ser, ou seja, é compreendendo que o ser-aí interpreta. Complementa-se essa ideia com o seguinte excerto: "no compreender, o ser-aí [sic] projeta seu ser para possibilidades. Esse ser para possibilidades em compreendendo é um poder-ser que repercute sobre o ser-aí [sic] as possibilidades enquanto aberturas. O projetar inerente ao compreender possui a possibilidade própria de se elaborar em formas. Chamamos de interpretação essa elaboração. Nela, o compreender apropria-se do que compreende. Na interpretação, o compreender vem a ser ele mesmo e não outra coisa” (HEIDEGGER, 2012, p. 209). 
início e do fim na ideia de círculo faz que o objeto da teologia seja sempre tomado de maneira nova. O objeto da teologia é sempre novo.

Esse posicionamento da questão "por que é possível algo como teologia?", então, é respondido não somente com um "por causa disso", mas sobretudo com um "como" (Wie) se viabiliza a ciência. Além disso, faz-se perceber outras duas conclusões interessantes para a continuidade deste trabalho: a primeira delas diz respeito à unidade no pensamento de Heidegger entre a colocação e o desenvolvimento da problemática acerca do ser. E daí perceber a unidade entre as obras desse período, conforme destaca Paulo Sérgio Gonçalves:

A unidade de todas essas obras [História da filosofia, de Tomás de Aquino a Kant (1926-1927), Ser e tempo (1927) e a conferência Fenomenologia e teologia (1927)] propicia que a questão do ser, de sua história e da análise de sua presença, traga à tona a distinção entre ciência e filosofia, a identificação entre filosofia, ontologia e fenomenologia, a vinculação entre fenomenologia e hermenêutica e a diferença ontológica entre ser e ente. Esta unidade é importante para que se compreenda que o conteúdo do texto Phänomenologie und Theologie se situa no contexto do próprio filosofar heideggeriano, em que se busca superar posições fechadas em determinadas sentenças (GONÇALVES, 2014, p. 938).

Essa unidade incide diretamente sobre a própria cientificidade da teologia, de onde a segunda conclusão: não se acessa a teologia "por fora", mas somente a partir da fé. Ou seja: a teologia não conduz à fé, mas, antes, é conduzida por ela. "É assim que a teologia pode permitir que a gravidade presente na credulidade, enquanto modo de existência 'doada', ganhe consciência” (HEIDEGGER, 2008, p. 67).

A possibilidade de isso acontecer é tão-somente porque a teologia é imbuída de caráter histórico, o que significa: ela se autointerpreta partindo sempre de um “agora” hermenêutico, no qual o ser-aí está predisposto a decidir. Esse “agora” hermenêutico é constituído de presente, passado revivificado e futuro antecipado: essa caracterização permite afirmar o "agora hermenêutico" como lócus próprio para compreender a dimensão historiológica da teologia, visto que esta está diretamente ligada ao ser-aí.

A teologia, enquanto ciência historiológica, compreende a existência cristã a partir da historicidade do ser-aí, desenvolvendo sempre a dinâmica hermenêutica compreensiva/interpretativa, atualizando o próprio evento crístico - Cristo, o Deus crucificado. Quando a teologia se percebe como 
ciência historiológica, a hermenêutica desenvolvida é então direcionada a si mesma: "a teologia é necessariamente hermenêutica, mas hermenêutica no sentido de que ela mesma se encontra implicada por causa daquilo que a constitui - a fé" (CAPELLE-DUMONT, 2012, p. 38; tradução do autor). ${ }^{12}$

O caráter historiológico da teologia, todavia, não pretende imiscuir a cientificidade das demais disciplinas teológicas. Não se pretende criar uma hierarquia de valores científicos para a teologia, mostrando que a dimensão histórica esteja acima de outras. Na verdade, a dimensão histórica encontra-se em todas as demais disciplinas, nas quais a teologia se articula. Por isso, "quanto mais historiológica for uma teologia, quanto mais diretamente ela colocar em palavra e conceito a historicidade da fé, tanto mais 'sistemática' e tanto menos escrava de um sistema ela será” (HEIDEGGER, 2008, p. 68). Essa anotação é muito significativa, pois liberta a teologia de um sistema metafísico. A teologia não pode se preocupar em elaborar proposições conclusivas genéricas, dotadas de a-historicidade e que tenham a pretensão de ser transmitidas como conhecimento. Vale relembrar: não se pode acessar a teologia por fora, ou seja, uma "teologia metafísica" cumpre um desfavor para a própria credulidade, pois a afasta da realidade existencial do ser-aí. A sistematicidade da teologia deve brotar do mais íntimo da própria fé e não como algo imposto desde fora:

Não se pode entender esta sistematicidade como a "elaboração de um siste-

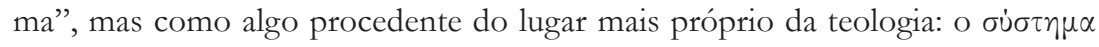
da crença. [...] A palavra "sistema" sofre aqui uma subversão de sentido: já não conota o desfecho da história em uma "lógica" abstrata, mas antes mostra a estreita proximidade com aquilo que, pela e na fé, acontece (CAPELLE-DUMONT, 2012, p. 39; tradução do autor). ${ }^{13}$

A sistematicidade da teologia, então, tanto mais histórica será quanto mais o conceito significar existencialmente. Quanto mais a teologia se deixar guiar pela cristicidade tanto mais teológica ela será. De onde a conclusão: "portanto, uma vez que seu caráter sistemático se dá na dependência da exis-

12 "La teología es necesariamente una hermenéutica, pero una hermenéutica en la cual ella misma halla implicada, a causa de aquello que la constituye - la fe."

13 "Esta sistematicidad no debe entenderse en el sentido en que apunte a la "producción de

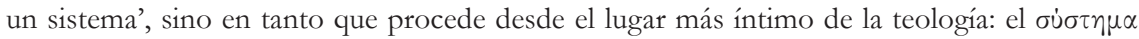
de la creencia. [...] La palabra 'sistema' sufre aquí, pues, una subversión de sentido: ya no connota el encierro de la historia en una 'logía' abstracta, sino la estricta proximidad con aquello que, por y en la fe, acontece." 
tência na fé, quanto mais historiológica, mais sistemática ela pode ser. Não há, dessa maneira, oposição entre o seu caráter historiológico e sistemático" (PIEPER, 2015, p. 113).

A própria historicidade aponta, então, para a existência fática do ser-aí. Logo, a dimensão histórica da teologia também traz em seu bojo o caráter prático da teologia em sua cientificidade. O caráter prático (práxis) da teologia tem uma dupla incidência relacionada à tarefa hermenêutica assumida pela própria teologia: a homilética e a catequética. Nota-se isso na seguinte passagem:

Ora, faz parte da auto-interpretação do acontecer cristão, enquanto um acontecer historial, apropriar-se sempre de novo de sua própria historicidade e da compreensão das possibilidades do ser-aí crente, possibilidades que cresceram no interior daquela historicidade. Mas visto que, tanto como disciplina sistemática quanto como histórica, a teologia tem como objeto o acontecer cristão em sua cristicidade e historicidade, que esse acontecer se determina como modo de existência do crente e que existir é, todavia, agir, práxis, a teologia, de acordo com sua essência, possui o caráter de uma ciência prática. Enquanto ciência do agir de Deus sobre o homem que age pela fé, ela já é "por natureza" homilética (HEIDEGGER, 2008, p. 69).

Esse caráter prático homilético aponta para a dimensão comunicativa do cristianismo. A fé não é fé isolada. A homilética é sempre carregada de historicidade. Essa dimensão não é encontrada somente em atos litúrgicos ou numa prática pastoral. Antes, o caráter prático da teologia deve estar presente em tudo aquilo em que a teologia se desdobra. A ausência do caráter prático coloca em questão a própria cientificidade teológica.

A homilética é o meio pelo qual a revelação dada pela fé é organizada e anunciada aos homens. Conforme aponta Gonçalves: "a homilética corresponde à própria natureza da palavra de Deus dirigida ao homem, que encontra na liturgia cristã, um lócus specialis, no qual a palavra se vincula ao mistério cristão e à sua revelação" (GONÇALVES, 2014, p. 947). Esse existir na fé, então, implica em um agir a partir da fé. Percebe-se também um movimento próprio à teologia em sua cientificidade: enquanto compreensão sistemática-historiológica da própria fé, ela não pode estar desvinculada da ação. Isso tudo possibilita reiterar a tese aqui assumida: enquanto ciência derivada, a teologia resguarda a dimensão originária da experiência crística.

A catequética, por sua vez, não é tornar praticável alguns enunciados teóricos, mas antes o próprio ensino aos homens da palavra revelada. Esse 
"ensino", isto é, a catequética, no entanto, merece uma atenção especial, pois ela torna possível perceber com maior nitidez a importância, sobretudo, dos indícios formais para a teologia: a catequética não pode, antecipadamente, determinar o conteúdo da fé, nem a referência (Bequg) de tal experiência e, muito menos, o sentido de realização (Vollz̧ug). Por isso, a catequética não é doutrinação, mas libertação. E, enquanto tal, não fixa padrões, mas conduz, sendo parceira do próprio agente da fé.

Essa ideia de parceria é a mesma apontada entre teologia, ciência ôntica, e filosofia, ciência ontológica: "a correção é entendida, aqui, como uma direção concomitante e secundária, como uma con-dução ou uma co-in-dução do significado do conceito" (FERNANDES, 2015, p. 106).

\section{Considerações finais}

A partir destas anotações pode-se, a modo conclusivo, indicar o seguinte: a cientificidade da teologia é sempre apresentada enquanto historiológico-sistemático-prática, conforme apontado com maior ênfase no terceiro momento deste texto. Isso também conduz a um alerta: privilegiar qualquer uma das três é prestar um desfavor à própria teologia. E mais: "a teologia só é sistemática se for prático-historial. A teologia só é historiológica se for prático-sistemática. A teologia só é prática se for historiológico-sistemática” (HEIDEGGER, 2008, p. 69). Tudo isso faz que seja feita uma grande exigência à realização de uma tarefa tal qual questionar a própria fé. A teologia é possível a partir desse caráter questionador fundamental, sua cientificidade também está aí ancorada. Em outras palavras: a construção ideal da teologia não visa a promoção de um conjunto metafísico de proposições, mas antes responder às próprias questões sobre a fé. $\mathrm{E}$, com isso, percebe-se por que Heidegger olha com tanta atenção para figuras como Paulo, Agostinho, Lutero, Bernardo de Claraval: estes são grandes questionadores da própria fé, capazes de expressar seu questionamento de maneira historiológico-sistemático-prática. Isso, no entanto, ultrapassa o recorte proposto por este trabalho e fica somente indicado a modo conclusivo.

Por fim, "a teologia se consolidará como ciência ôntica por assumir sua identidade de fé cristã, constituída de existência humana, podendo melhor falar de Deus, porque sua linguagem estará cada vez mais aberta ao novum desse mesmo Deus" (GONÇALVES, 2014, p. 954). E mais: enraizado a isso está o caráter existencial da própria teologia, responsável por conduzir o ser-aí a um questionar sobre o próprio ser, descobrindo sempre o novum da 
revelação de Deus. Essa conclusão se coaduna ao segundo tópico do presente texto, pois ali se destacou a positividade da teologia, mostrando, inclusive, que o positum da teologia é sempre novo.

Dessa maneira, a conferência Fenomenologia e teologia torna possível a afirmação de que a teologia é um modo de compreensão da fé. Esse modo é dotado de positividade e cientificidade e, mantendo seu caráter ôntico, relaciona-se com a fenomenologia, dotada de caráter ontológico, colocando a própria teologia como um desdobramento fático-hermenêutico da existência.

\section{Referências}

CAPELLE-DUMONT, Philippe. Filosofía y teologia en el pensamiento de Martin Heidegger. Buenos Aires: Fondo de Cultura Económica, 2012.

FERNANDES, Marcos Aurélio. Fenomenologia e teologia em Martin Heidegger. Reflexão. Campinas, v. 40, n. 1, 2015, p. 95-108.

GONÇALVES, Paulo Sérgio Lopes. A teologia como ciência ôntica e sua relação com a filosofia. Horizonte. Belo Horizonte, v. 12, n. 35, 2014, p. 932-956.

GONÇALVES, Paulo Sérgio Lopes. Ontologia hermenêutica e teologia. Aparecida: Santuário, 2011.

HEIDEGGER, Martin. Fenomenologia da vida religiosa. Trad.: Enio Paulo Giachini; Jairo Ferrandin; Renato Kirchner. Petrópolis: Vozes; Bragança Paulista: Editora Universitária São Francisco, 2010.

HEIDEGGER, Martin. Fenomenologia e teologia. In: Marcas do caminho. Trad.: Enio Paulo Giachini e Ernildo Stein. Petrópolis: Vozes, 2008, p. 56-88.

HEIDEGGER, Martin. História da filosofia, de Tomás de Aquino a Kant. Trad.: Enio Paulo Giachini. Petrópolis: Vozes, 2009.

HEIDEGGER, Martin. Ser e tempo. Trad.: Márcia de Sá Cavalcanti. Petrópolis: Vozes, 2012.

PIEPER, Frederico. Filosofia e teologia em Heidegger: notas sobre a conferência "Fenomenologia e teologia" de 1927. Numen: revista de estudos e pesquisa da religião. Juiz de Fora, v. 17, n. 2, 2015, p. 99-134.

SANTOS, Bento Silva. Fenomenologia e idade média. Curitiba: CRV, 2013.

SANTOS, Bento Silva. Martin Heidegger e a mística medieval: em busca de uma compreensão fenomenológica. Síntese: revista de filosofia. Belo Horizonte, v. 43, n. 136, 2016, p. 279-303.

Submetido em: 20-12-2016

Aceito em: 18-7-2017 